\author{
Dorota Muszytowska \\ Uniwersytet Kardynała Stefana Wyszyńskiego w Warszawie \\ ORCID: 0000-0001-5873-382X
}

\title{
Enkomion mądrości i jego funkcja perswazyjna w Księdze Mądrości
}

\begin{abstract}
Abstrakt: Księga Mądrości uznawana jest za spójny tekst charakteryzujący się synkretyzmem gatunkowym. Celem niniejszego artykułu jest przebadanie zawartej w Księdze Mądrości pochwały mądrości pod kątem jej perswazyjnych funkcji w utworze.

Do badań wykorzystano enkomion jako gatunek typowy dla retoryki epideiktycznej. Tekst pochwały został przeanalizowany z perspektywy cech wyróżniających ten gatunek i decydujących o jego bazowej strukturze.

Analizy doprowadziły do wniosku, że autor wykorzystał możliwości gatunku, aby pouczyć odbiorców, o jaką mądrość powinni zabiegać i by skłonić ich do podjęcia działań zmierzających do jej osiągnięcia. Enkomion w Księdze Mądrości został podporządkowany retoryce doradczej i stanowi ważny element w strukturze utworu.
\end{abstract}

Słowa kluczowe: Księga Mądrości, enkomion, pochwała mądrości, retoryka epideiktyczna, retoryka symbuleutyczna

\section{Wstęp}

Jednym z istotnych fragmentów Księgi Mądrości jest zawarta

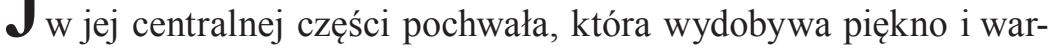
tość mądrości. Autor utworu nie tylko ma ambicje zdefiniowania tego, co rozumie przez mądrość, ale także wielokrotnie posługuje się wezwaniami do odbiorców, które mają zachęcić ich do tego, by uznali ową mądrość za kluczową wartość, która będzie rządziła ich decyzjami i wyborami. Utwór świadczy o kunszcie literackim i retorycznym autora. Wykorzystał on wiele znanych i czytelnych dla jemu współczesnych odbiorców sposobów wypowiedzi - jednym z nich jest enkomion. Choć to typowo epideiktyczny gatunek, w tradycji greckiej literatury i retoryki wykorzystywany był często 
także w dwóch pozostałych typach perswazji - doradczym i osądzającym. Celem niniejszego artykułu jest pokazanie, jak autor posłużył się tą formą do osiągnięcia swoich celów: przekonania odbiorców do dokonania wyboru postawy nieustannego poszukiwania Bożej Mądrości i uczynienia z niej punktu odniesienia dla swoich decyzji i postępowania w życiu.

\section{Problematyka rodzaju retorycznego Księgi Mądrości}

Dominanta zastosowanej w Księdze Mądrości retoryki jest tematem, któremu badacze tej księgi poświęcali niewiele uwagi. Wciąż brakuje dogłębnych opracowań badających i opisujących szczegółowo sferę perswazyjną utworu jako całości, zarówno jeśli chodzi o jego warstwę argumentacyjną, jak i elokucyjną wykorzystaną do zbudowania argumentacji. Zauważanie walorów perswazyjnych Księgi Mądrości wyrasta bowiem zazwyczaj na marginesie badań nad strukturą utworu oraz nad zastosowanymi w nim gatunkami literackimi czy stylem autora ${ }^{1}$. Badania nad genologią Księgi Mądrości przyniosły ciekawe spostrzeżenia także w zakresie jej retoryczności. Po pierwsze, przy ocenie gatunku całego utworu większość badaczy uznaje, że jest to protreptyk ${ }^{2}$. Jest to rodzaj literatury ekshortacyjnej, wyrosły

1 Ważne prace z tego zakresu to: J.M. Reese, „A Semeiotic Critique”, 229-242; L.G. Perdue, „Rhetoric and the Art of Persuasion”, 341-371. Perdue nakreśla problem w szerszej perspektywie - funkcjonowania retoryki w hellenistycznym społeczeństwie, jej wpływu na literaturę i sposobu prowadzenia dyskursu, a w związku z tym także możliwości recepcji i interpretacji tego utworu głównie w środowisku zhellenizowanych Żydów. Za ważną, chociaż podejmującą kwestie retoryczności Księgi Mądrości w węższej perspektywie, dostarczającą argumentów na rzecz retoryki deliberatywnej Księgi Mądrości i opisującą sposoby jej wykorzystania w tym utworze, należy uznać monografię J.R. Dodsona - The 'Powers' of Personification.

2 Najważniejszą pracą, podejmującą problem rodzaju i gatunku literackiego Księgi Mądrości jako spójnego jednolitego utworu, jest monografia J.M. Reese'go, Hellenistic Influence on the Book of Wisdom, 117-121, gdzie opowiada się on za protreptikos logos. Jego opinię poprzedził np. A. Dupont-Sommer (por. „De l'immoralité astrale", 80), który cechy protreptyku dostrzegał w Mdr 1-10. Za opinią J.M. Reese'go, że cały utwór można traktować jako protreptyk, poszli D. Winston (Wisdom of Solomon, 18), G.W.E. Nickelsburg (Jewish Literature, 175), S.J. Tanzer (,The Wisdom of Solomon”, 293-294), B. Poniży (Księga Mądrości, 54). 
na gruncie filozofii i retoryki. Protreptikos logos wykorzystywany był w równej mierze przez filozofów i oratorów. Charakterystyczne dla niego jest połączenie rodzajów retorycznych symbuleutycznego i epideiktycznego, przy czym cechy epideiktyczne są podporządkowane celom symbuleutycznym ${ }^{3}$. Po drugie, badania te zwróciły uwagę na bardziej złożony, synkretyczny charakter utworu, w którym autor posłużył się wieloma wzajemnie uzupełniającymi się formami ${ }^{4}$. Wyróżnianymi gatunkami są tu: protreptyk, enkomion, eulogia, panegiryk, epitafium, egzemplum, diatryba, synkrisis, oskarżenie i obrona (kathegoria i apologia).

Już same gatunki wypowiedzi literackiej użyte w tekście wskazują na to, że mamy do czynienia $\mathrm{z}$ różnymi typami perswazji, ponieważ na przykład enkomion, penegiryk i epitafium właściwe są dla epideiktyki, egzemplum dla symbuleutyki, dla retoryki sądowejoskarżenie i obrona. Jeśli jeszcze weźmiemy pod uwagę, że część gatunków wypowiedzi wykorzystanych przez autora Księgi Mądrości, jak synkrisis czy protreptyk, to z założenia formy łączące różne typy perswazji, to wniosek o niejednorodnej retoryce w tej Księdze wydaje się być jak najbardziej uprawniony.

Gatunki składające się na Księgę Mądrości nie stanowią jednak luźnej konstrukcji typu antologicznego, lecz tworzą wysublimowaną, harmonijną strukturę proporcjonalnie rozłożonych w całości utworu stychów, powiązanych inkluzjami, strukturę opartą na koncepcji złotego środka w greckiej poetyce lirycznej ${ }^{5}$. Trudno byłoby utrzymywać, że przy tak misternie skonstruowanej wypowiedzi jej siły i akcenty perswazyjne autor pozostawił przypadkowi, skoro jego celem było przekazanie odbiorcom pouczenia o roli mądrości. Tym bardziej że już przy pierwszej lekturze można zauważyć w tym

3 Por. T.Ch. Burgess, Epideictic Literature, 112-113; M. Jordan, „Ancient Philosophic", 309-333.

4 Więcej na ten temat, zob. np. B. Poniży, Księga Mądrości, 51-55. Na temat wpływu literackich i retorycznych tradycji na tekst Księgi Mądrości zobacz J.M. Reese, Hellenistic Influence on the Book of Wisdom.

5 Zobacz szczególnie: H.S.J. Thackeray, „Rhythm in the Book of Wisdom”, 232-237; L. Maries, „Remarques sur la forme poétique”, 251-257; P.W. Shekan, „The Text and Structure”, 1-12; A.G. Wright, „Numerical Patterns”, 524-538; E.D. Reymond, „The Poetry of the Wisdom”, 385-399. 
utworze specyficzną obecność mówcy, który choć jest anonimowy, przemawia także do odbiorców siłą swojego etosu, co wyraźnie potwierdza zamierzone działanie autora. Księga Mądrości nie jest oczywiście zapisem typowej retorycznej mowy, ale dojrzałą literaturą i należałoby rozpatrywać jej cechy perswazyjne w kategoriach retoryki literackiej. Wielość gatunków, ich różna proweniencja i celowość oraz właściwe im cechy retoryczne wyraźnie wskazują, że Księga Mądrości pod względem retorycznym nie może być monolitem gatunkowym, co nie jest jednoznaczne z tym, że obecna wieloretoryczność wyklucza dominację i celowość jednego, typu perswazji.

Ze względu na sapiencjalny charakter utworu można z góry przyjąć założenie, że w Księdze Mądrości mamy do czynienia z retoryką doradczą. Do natury literatury dydaktycznej należy bowiem doradzanie tego, co właściwe, i odradzanie tego, co niewłaściwe, bez względu na to, czy literatura ta ma charakter teoretyczny i rozważa, co i kiedy jest słuszne (godziwe), a co niesłuszne (haniebne), czy też ma charakter praktyczny i przynależy do nurtu protreptyki i apotreptyki. Trzeba jednak pamiętać, że przypisanie literaturze sapiencjalnej cech właściwych perswazji symbuleutycznej, opierającej się na kwalifikacji tego co godziwe, użyteczne i korzystne - co jest odbiorcom zalecane oraz co niegodziwe, nieużyteczne i niekorzystne - co się odbiorcom odradza, wcale nie musi oznaczać, że w tekście utworu dydaktycznego pojawiają się tylko cechy właściwe jednemu rodzajowi retoryki. Co więcej, w dobrze zbudowanym rodzaju doradczym, z założenia powinny pojawić się sposoby wypowiedzi właściwe i retoryce sądowej (zwłaszcza kiedy mamy do czynienia z wątpliwością lub kwestią sporną), i demonstratywnej (gdy dokonujemy oceny i amplifikujemy lub deprecjonujemy przedmiot przez pochwałę i przeciwną jej naganę). Wszystkie zabiegi retoryczne właściwe retoryce sądowej czy popisowej są wówczas podporządkowane nadrzędnemu celowi przedkładanego pouczenia po to, aby wykorzystać pełen wachlarz możliwości skłonienia odbiorców do podjęcia właściwej decyzji i związanego z nią działania, którego mówca oczekuje.

W analizie retorycznej, posługując się arystotelesowym wyznacznikiem temporalnym w odniesieniu do zamierzonego przedmiotu mowy, możemy ocenić, który z typów retoryki dominuje. Najogólniej mówiąc, typ perswazji zastosowanej w istniejącym tekście możemy 
rozpoznać po tym, do jakiego czasu odnosi się przedmiot mowy: przeszłego, teraźniejszego czy przyszłego. Odnoszenie się do przeszłości, rozstrzyganie i dokonywanie osądu to cechy charakterystyczne dla rodzaju retoryki jurydycznej. Gdy zaś przedmiot mowy i jego kwalifikacja osadzone są w teraźniejszości, unaocznia się odbiorcy ów przedmiot - mamy do czynienia z retoryką popisową. Jeśli natomiast zakłada się przyszły wybór i decyzję odbiorcy, to przedmiot poruszanej sprawy odnosi się do przyszłości, ponieważ ukazuje odbiorcom skutki ich hipotetycznych decyzji. Jest to równoznaczne z posługiwaniem się retoryką doradczą ${ }^{6}$. Jeśli przyłożymy takie kryterium do Księgi Mądrości, możemy stwierdzić obecność wszystkich trzech rodzajów retoryki ${ }^{7}$. Idąc za opiniami większości badaczy i przyjmując trójczęściową strukturę utworu, można dokonać przyporządkowania rodzaju retorycznego do poszczególnych części. Uproszczony schemat przedstawiono w Tabeli $1^{8}$ :

Tabela 1. Przyporządkowanie rodzaju retorycznego do poszczególnych części Księgi Mądrości

\begin{tabular}{|l|l|l|}
\hline \multicolumn{1}{|c|}{ Część utworu } & \multicolumn{1}{|c|}{ Cel autora } & \multicolumn{1}{|c|}{ Rodzaj retoryki } \\
\hline $\begin{array}{l}\text { Księga } \\
\text { eschatologii } \\
1,1-6,21\end{array}$ & $\begin{array}{l}\text { Ukazywanie odbiorcom przyszłej } \\
\text { perspektywy }\end{array}$ & Retoryka doradcza \\
\hline $\begin{array}{l}\text { Księga } \\
\text { mądrości } \\
6,22-9,18\end{array}$ & $\begin{array}{l}\text { Pochwała mądrości i postawy jej } \\
\text { poszukiwania }\end{array}$ & $\begin{array}{l}\text { Retoryka } \\
\text { popisowa }\end{array}$ \\
\hline $\begin{array}{l}\text { Księga historii } \\
10-19\end{array}$ & $\begin{array}{l}\text { Ocena wydarzeń i postaw ludzkich od } \\
\text { początków stworzenia do wydarzeń } \\
\text { związanych z Exodusem }\end{array}$ & $\begin{array}{l}\text { Retoryka } \\
\text { jurydyczna }\end{array}$ \\
\hline
\end{tabular}

Takie przypisanie rodzajów retoryki z jednej strony sugeruje, że żaden z nich nie przeważa w całości utworu, z drugiej strony zaś, zdecydowanie wskazuje na dominującą obecność wybranego rodzaju retorycznego w poszczególnych częściach Księgi Mądrości. Jest to

6 Arystoteles, Rhetorica $1.1358 \mathrm{~b}$.

7 Por. L.G. Perdue, „Rhetoric and the Art of Persuasion”, 360-361.

8 Schemat wyodrębniający trzy księgi w Księdze Mądrości (eschatologii, mądrości i historii) zaczerpnięty z B. Poniży, Księga Mąrości, 98. Więcej na temat badań nad złożoną problematyką dotyczącą struktury utworu zob. M. Gilbert, „The Literary Structure of the Book of Wisdom", 19-32. 
jednak bardzo schematyczne i nie w pełni odzwierciedla złożoną rzeczywistość tekstu. W „Księdze historii” można na przykład zauważyć elementy typowe dla synkrisis lub też dla doradczego, a nie jurydycznego, narratio. Zestawia się tam wydarzenia nie po to, aby je unaocznić odbiorcy w roli sędziego, aby został dokonany właściwy osąd na podstawie faktów. Prezentowane wydarzenia są już osądzone i jako takie są przedstawiane - przynoszące korzyść i dobro jednym (posłusznym Bogu), a utrapienia i zgubę drugim (sprzeciwiającym się Bogu). Jest to więc albo wyrafinowana konstrukcja porównania, służąca doradzaniu odbiorcom, aby opowiedzieli się po tej samej stronie co ci, którzy wówczas dokonali właściwego wyboru, albo kompozycja narracyjnej epideiktyki, w której ukazuje się wydarzenia od razu z perspektywy pochwały i nagany, jednak nie tyle samych wydarzeń, które jako takie są neutralne, co postaw ludzi, którzy w nich uczestniczyli. Chociaż więc mamy w tej części Księgi Mądrości przywołanie przeszłych wydarzeń, to nie są one rzeczywistym przedmiotem odniesienia w mowie. Odbiorca nie ma o nich rozstrzygać, mimo że stanowią istotną materię dowodową. Ta narracja epideiktyczna nie służy jednak tylko temu, by jednych pochwalić a innych zganić, choć odzwierciedla znane z literatury retorycznej mowy pochwalne i naganne narodów czy mieszkańców miast ${ }^{9}$. Narracja ta pełni tu funkcję egzemplum, prowadzącego odbiorców do przyjęcia właściwej postawy, ostatecznie więc pozostaje bliższa nurtowi retoryki symbuleutycznej.

Już tak uogólniona analiza rodzajów retoryki zastosowanych w Księdze Mądrości skłania do większej wnikliwości w ich ocenie - zwłaszcza gdy weźmiemy pod uwagę, że poszczególne elementy argumentacji i wykorzystane gatunki wypowiedzi, mając swoją pierwotną nośność perswazyjną, zyskują często nową jakość retoryczną, kiedy są elementem większej całości, i w takiej perspektywie ostatecznie powinny być oceniane.

9 Zob. np. Dio Chryzostom, Orationes. 


\section{Enkomion jako gatunek literacki i jego możliwości perswazyjne}

Enkomion należy do form wypowiedzi, które rozwinęły się na gruncie retoryki epideiktycznej, oscylującej wokół pochwały i nagany ${ }^{10}$. Terminologia powiązana $\mathrm{z}$ enkomionem jest stosowana także w szerszym zakresie: literatury enkomiastycznej, czyli pochwalnej, oraz na oznaczenie stylu laudatywnego. W sensie ścisłym enkomion uważany jest za gatunek wypowiedzi o charakterze pochwalnym. Może on być zrealizowany zarówno w formie poetyckiej, jak i prozatorskiej. Pierwotnie enkomion pojawił się w poezji jako pieśń pochwalna na czyjąś cześć, ewoluował w melikach. Gatunkiem tym posługiwali się Symonides, Pindar, Bakchylides i inni poeci. Pokrewny jest hymnowi, w którym przedmiotem pochwały byli bogowie, epitafium (gr. epitafios) - mową pogrzebową, opiewającą życie i czyny zmarłych, a także zbliżony jest do epinikionu, czyli pieśni pochwalnej na cześć zwycięzców, różniącej się jednak od enkomionu pod względem rytmu i muzykalności, ponieważ epinikion był liryką chóralną ${ }^{11}$. Przedmiotem enkomionu mogło być to, co jest godne pochwały (np.: ludzie i ich czyny, cnoty, wartości, krainy, miasta, porty, zwierzęta, rośliny, wydarzenia $)^{12}$. Zasadniczo w poezji nie używano tego gatunku w funkcji pejoratywnej (np. w celach ironizacji czy apologii), dopiero później w komediach i w retoryce stosowano pochwały w celu uzyskania efektu ośmieszenia (tzw. paradoksa enkomia) ${ }^{13}$.

10 Dwie ważne monografie dotyczące retoryki epideiktycznej bierzemy tu pod uwagę: niezwykle cenne opracowanie Epideictic Literature (1902) T.Ch. Burgessa, który przedstawił różne formy epideiktycznych wypowiedzi w starożytności, ich funkcje perswazyjne oraz praktykę ich stosowania, oraz monografię L. Pernot, Epideictic Rhetoric. Questioning the Stakes of Ancient Praise (wersja oryg. z 1993 r.), który przyjął inne od Burgessa założenia metodologiczne, stawiając sobie za cel ukazanie rozwoju form epideiktyki, bazował jednak w przeważającej mierze na opracowaniach teoretyków, co stanowi pewną metodologiczną lukę.

11 Na temat początków rozwoju enkomionu zob. L. Pernot, Epideictic Rhetoric, $1-28$.

12 Zob. np. Arystoteles, Rhetorica 1.1367a-1368b; Teon z Aleksandrii, Progymnasmata 110-112; Aftoniusz Sofista, Progymnasmata 35-36.

13 Niektórzy (np. Izokrates) w ogóle wykluczali takie cechy w enkomionach, niektórzy zaś uznawali, że jest to podyktowane sytuacją, ale nie powinno być celem wypowiedzi enkomiastycznej jako takiej i powinno być zawsze dobrze wyjaśnione 
Enkomion jako forma retorycznej wypowiedzi ulegał przemianom i rozwojowi z praktyką jego stosowania w życiu społecznym, prywatnym i publicznym. Wraz z rozwojem formy stawał się przedmiotem zainteresowania i opisu teoretyków retoryki. Oczywiście trudno jest zakładać, że formy enkomionu, które najlepiej opisane są w pracach zdecydowanie późniejszych w stosunku do potencjalnej datacji powstania Księgi Mądrości, jak Kwintyliana, Hermogenesa, Pseudo-Dionizego z Halikarnasu, Menandra Retora, Aftoniusza Sofisty, Mikołaja z Myry, Libaniosa i innych, mogły wywrzeć jakikolwiek wpływ na jej autora. Dlatego odnoszenie się do ich prac w niniejszym opracowaniu jest świadome tego metodologicznego zastrzeżenia, ale z założeniem, że znaczna część przedstawionych przez nich teorii była praktykowana już we wcześniejszym okresie, co widać w mowach Izokratesa, Demostenesa, u Platona, a także w opracowaniach teoretycznych, takich jak Retoryka dla Aleksandra Anaksymenesa z Lampsakos i Retoryka Arystotelesa ${ }^{14}$. Szczególnie dwa wyżej wspomniane dzieła oraz ujęcia epideiktyki i enkomionu u Teona i Cycerona (zwłaszcza moralny potencjał pochwały i nagany, por. De oratore, 69-70), jako kontynuacji wcześniejszej tradycji, są tu wyznacznikiem odnoszenia się do pojmowania perswazji enkomionu w Księdze Mądrości, przy czym arystotelesowy „pokaz” rozumiemy jako skupienie uwagi odbiorcy na przedmiocie pochwały, a nie jako przestrzeń do popisów oratorskich ${ }^{15}$. Szczególnie ważne

w przebiegu mowy, aby nie pozostawiało w odbiorcy wątpliwości. Więcej na ten temat zob. T.Ch. Burgess, Epideictic Literature, 118-119, na temat paradoksa enkomia $157-166$.

14 Por. C. Pepe, The Genres of Rhetorical Speeches, 41-55, 61-78, 243-384.

15 Takie pojmowanie epideiktyki przypisywane często poglądom Arystotelesa jest raczej wynikiem nazbyt schematycznej interpretacji. Chociaż Arystoteles w swojej teorii retorycznej nie poświęcił jej tyle uwagi, co pozostałym wyróżnianym przez niego rodzajom retorycznym, co jest niewątpliwie mankamentem tego opracowania, to nie oznacza, że zastrzegał tę formę w przestrzeni publicznej dla zmagań w zawodach oratorskich, w których rolą odbiorcy była ocena efektu. Przypisanie epideiktyki do oratorskich popisów należy raczej w teorii Arystotelesa traktować jako wskazanie na to, co stanowi model dla takiej perswazji, analogicznie do tego, że retoryka osądzająca ma swoje podłoże w rozprawie sądowej, a doradcza w politycznym, publicznym zgromadzeniu. Nie oznacza to, że Arystoteles zastrzegał stosowanie perswazji tylko do takich sytuacji jak sąd, polityczna debata czy 
jest dla nas ujmowanie przez Arystotelesa epideiktyki jako formy wypowiedzi literackiej ${ }^{16}$, a w znacznie mniejszym stopniu praktyki oralnej, co w odniesieniu do Księgi Mądrości jako rozbudowanego utworu literackiego ma swoje uzasadnienie. Zmiana jaka następuje w epoce późnego cesarstwa, po kryzysie w III w., i rozkwit nowych form wypowiedzi epideiktycznych, nie mają większego znaczenia dla pojmowania enkomionu w Księdze Mądrości. Istotne natomiast mogą być spostrzeżenia Kwintyliana na temat oceniającej funkcji epideiktyki i w związku z tym jej dużego potencjału pedagogicznego i możliwości wykorzystania zarówno w dydaktyce, jak i w publicznym życiu społecznym. Nie dlatego, że spostrzeżenia te stanowiły novum, ale z uwagi na to, że jego teoretyczne opracowanie - które w dużej mierze można uznać za efekt popularności retorycznych form epideiktyki w życiu społeczeństwa rzymskiego, szczególnie okresu wczesnego cesarstwa - tak naprawdę jest pewnego rodzaju recepcją wcześniejszych tradycji, powiązanych nade wszystko z dworską epideiktyką hellenistyczną. Ta ostatnia rozwija się wraz z epoką aleksandryjską, w której potencjał dydaktyczny epideiktyki, wpajanie odbiorcom określonych wartości, był praktykowany nie tylko w enkomionach na cześć władców ${ }^{17}$.

Enkomion, podobnie jak i wiele innych form poetyckich, został zapożyczony z liryki i przeniesiony na grunt prozy retorycznej i w jej obrębie się rozwijał. Wielu teoretyków, definiując enkomion jako gatunek wypowiedzi retorycznej, odnosi się ściśle do tego, co pierwotnie oznaczał on w liryce. Stąd i w retoryce został zaklasyfikowany

zawody oratorskie. Dyskusję prowadzoną wśród badaczy na ten temat przedstawia np. C. Pepe, The Genres of Rhetorical Speeches, 140-159.

16 Zob. Arystoteles, Rhetorica 3.1413b-1414a.

17 Nie do końca uzasadnione wydaje się być twierdzenie L. Pernot, który uważa, że dopiero w okresie cesarstwa rzymskiego w epideiktyce następuje przełom, ze względu na uwzględnianie różnych okoliczności związanych z tworzeniem pochwał (czas, miejsce, odbiorcy, cel). Enkomion przestaje być wówczas traktowany jako prosta, uniwersalna forma, pasująca do wielu okazji. Zob. L. Pernot, Epideictic Rhetoric, 19-20. O ile słuszne jest zauważenie, że wtedy następuje rozwój nowych gatunków mów pochwalnych, rządzących się często własnymi zasadami podyktowanymi celem, ich usamodzielnienie się, to uznawanie, że wcześniejsze enkomiony są skostniałe w formie ze względu na ograniczenia w pojmowaniu funkcji epideiktyki, jest nadmiernym uproszczeniem. 
jako rozbudowana wypowiedź mająca charakter dłuższego wywodu typu epideiktycznego ${ }^{18}$.

Principium dla wypowiedzi enkomiastycznej jest wywołanie przyjemności u odbiorcy, ale może także prowadzić do odczuć negatywnych, takich jak zazdrość. Podobne ryzyko jest wpisane w każdą mowę, która jest w sposób szczególny nastawiona na odbiorcę $^{19}$. Nie oznacza to jednak, że funkcja delectare jest wynikiem samego brzmienia słów, środków stylistycznych, umiejętności mówcy itp. Rodzi się ona także z upodobania w tym, co szlachetne, dobre, piękne - ma więc o wiele szersze odniesienie niż samo piękno słowa ${ }^{20}$. Owo upodobanie tworzy przestrzeń wpływania na odbiorcę, kształtowania jego poglądów, podejmowania określonych decyzji. W przestrzeni dyskursu dotyczącego perswazji od razu zauważono większe możliwości enkomionu, który może pozostać samodzielną mową pochwalną (głównie w odniesieniu do człowieka, jego przymiotów i dzieł), ale może też stanowić część innej wypowiedzi, jako element argumentacji, w której pochwała jest wykorzystywana do osiągnięcia celów perswazyjnych innych niż laudacja. U Demostenesa w $O$ wieńcu znajdziemy wykorzystanie enkomionu w retoryce sądowej, w politycznej demegorii, gdzie pochwała jednej osoby (samopochwała Demostenesa) w rzeczywistości staje się atakiem na przeciwnika (Ajschinesa), który staje się oskarżonym przez wykazywanie mu oszczerstw ${ }^{21}$. U Izokratesa w Panegiryku pochwała Aten służy nade wszystko celom retoryki symbuleutycznej; jest użyta, aby wykazać słuszność prawa Aten do hegemonii i wypływający z niej pożytek ${ }^{22}$. Ze względu na pewnego rodzaju alternatywę wpisaną także i w retorykę epideiktyczną, poprzez charakterystyczne dla niej przeciwstawienie pochwały i nagany, nawet wtedy, kiedy $\mathrm{w}$ argumentacji pojawia się tylko pochwała, odbiorca będzie ją odczytywał jako argument przemawiający na korzyść proponowanej

18 Taki sposób rozumienia enkomionu widać u Arystotelesa i Anaksymenesa. Zob. Rhetorica 1368a oraz Rhetorica ad Alexandrum 1440b, ale także u Cycerona, De oratore 42 i u Kwintyliana, Institutio oratoria 3.4.6; 8.3.11.

19 Por. L. Pernot, Epideictic Rhetoric, 111-112.

${ }_{20}$ Por. Arystoteles, Rhetorica 1366a; Cyceron, De oratore 2.341.

${ }_{21}$ Zob. np. Demostenes, De corona 246-247, 257, 268-269.

${ }_{22}$ Zob. Izokrates, Panegyrikos 21-100. 
mu tezy lub wyboru, bo w domyśle alternatywa będzie tym, co zasługuje na naganę. Enkomion w argumentacji pełni więc często funkcję wspomagającą dla dowodzenia i przekonywania. I to nie tylko w charakterze środka wywołującego u odbiorców pożądane emocje. Najłatwiej przez pochwałę jest uzyskać efekty patetyczne (pathos), poruszające emocjami odbiorców i pozwalające ich pozyskać dla przedstawianych im racji z uwagi na to, że typowym sposobem wypowiedzi w enkomionie jest amplifikacja ${ }^{23}$. Możliwości argumentacyjne enkomionu są jednak znacznie silniejsze, bo wykorzystuje się w nim także przekonywanie logiczne i odwołujące się do etosu, kształtujące poglądy i utrwalające postawy życiowe ${ }^{24}$. Widać to szczególnie w późniejszych formach enkomionów, zwłaszcza okresu cesarstwa, kiedy stał się powszechnie używaną formą wypowiedzi związaną ze stylem życia społecznego i kiedy chętnie wykorzystywano enkomion także w celach dydaktycznych ${ }^{25}$.

Retorzy zalecali kilka charakterystycznych elementów disposito enkomionu oraz właściwych mu topoi, które pozwalały osiągnąć zamierzoną skuteczność tej formy wypowiedzi pojmowanej modelowo jako pochwała osoby. Ramę stanowiły wstęp (prooimion) i zakończenie (epilogos), którego funkcję mogła spełniać modlitwa. Model pochwały wypełniano takimi elementami jak: genos - to, co związane jest z pochodzeniem (jak naród, ojczyzna, przodkowie, rodzice), anatrophe- - to, co związane jest z wychowaniem (jak godni nauczyciele, praktykowanie zdobywanych cnót, nabyte umiejętności, obyczaje, poszanowanie praw) i praxeis, czyli działania, dokonania, które porządkowane były według dóbr duszy (jak np.: rozsądek, sprawiedliwość, umiarkowanie, męstwo, odwaga, wytrwałość, opanowanie), dóbr ciała (jak np.: uroda, wzrost, siła, szybkość, zwinność) i dóbr zewnętrznych, związanych z powodzeniem, szczęściem, losem (jak bogactwo, przyjaciele, możliwości wykazania się znamienitymi czynami). Przed epilogiem zalecano także stosowanie porównania z dokonaniami innych (synkrisis). Były to zalecenia tworzące rodzaj

23 Por. Arystoteles, Rhetorica 1.1368 a.

24 Por. C. Pepe, ,(Re)discovering a Rhetorical Genre”, 26.

25 Więcej na temat rozwoju enkomionu w czasach rzymskich okresu cesarstwa zob. np. L. Pernot, Epideictic Rhetoric, 20-28. 
modelu, pozostawiające autorom pochwał swobodę w zakresie zastosowania poszczególnych elementów i stopnia ich wykorzystania, bo o tym decydowała sytuacja retoryczna, wyznaczająca cel tworzenia enkomionu i sam przedmiot pochwały. Układ podjętych pochwał w mowie mógł być różny. Dispositio nie stanowiło sztywnego schematu. Niekiedy konstruowano pochwałę, posługując się strukturą pierścieniową, chiastyczną, niekiedy koncentryczną, gdzie w części centralnej umieszczano najważniejszą cnotę lub najbardziej chwalebny czyn ${ }^{26}$.

\section{Dispositio i nośność perswazyjna enkomionu mądrości w Księdze Mądrości}

Nie ma konsensusu wśród komentatorów Księgi Mądrości odnośnie granic pochwały mądrości ${ }^{27}$. Wynika to z różnych założeń, jakie przyjmują badacze, dokonując podziału tego utworu na poszczególne elementy struktury. Najczęściej określenie „pochwała mądrości” stosuje się do jednostki tekstualnej Mdr 6,22-9,18 ze względu na ujawniający się tam podmiot liryczny, wypowiadający się w pierwszej osobie jako mędrzec, władca obdarowany Bożą Mądrością ${ }^{28}$.

Niektórzy jednak włączają w pochwałę mądrości także inne fragmenty, wyznaczając jej początek już od ekshortacji do władców o to, by nauczyli się mądrości w Mdr 6,9 lub od Mdr 6,12, kiedy mówi się o niezbywalnych przymiotach mądrości, uznając te wersety za wprowadzenie do dalszej pierwszoosobowej wypowiedzi pochwalnej $^{29}$. Jeszcze inni uznają za wersety Mdr 6,22-25 typowy transitus - fragment, który stanowi podsumowanie wcześniejszych

${ }^{26}$ Na temat propozycji dotyczących topiki, schematów dispositio enkomionu oraz reguł ich stosowania przedkładanych przez różnych autorów starożytnych zob. T.C. Burgess, Epideictic Literature, 120-142; L. Pernot, Epideictic Rhetoric, 31-42.

27 J.M. Reese, Plan and Structure, 391-399; A.G. Wright, The Structure of the Book of Wisdom, 165-184.

28 Por. np. J. Vílchez, Księga Mądrości, 800.

29 Por. np. U. Offerhaus, Komposition und Intention, 52-53; M. McGlynn, Divine Judgment, 22-23. 
ekshortacji, będący zarazem łącznikiem z dalszą częścią pochwalną, ale nie stanowiący w pełni jej integralnej części ${ }^{30}$.

Podobnie sytuacja się ma z ustaleniem końca pochwały mądrości. Na przykład, fragment Mdr 10,1-11,1 traktuje się albo jako przynależną część pochwały mądrości, będącą jej zakończeniem, albo jako transitus, pełniący z jednej strony funkcję podsumowania pochwały, a z drugiej wprowadzenia do narracji ukazującej działanie Bożej Mądrości w egipskich dziejach Izraelitów w przeszłości ${ }^{31}$.

Niekiedy pochwałą mądrości w opracowaniach nazywa się tylko krótki fragment od Mdr 7,22 do 8,1 lub do 8,21, zawierający laudację dwudziestu jeden przymiotów mądrości, będący częścią centralną mowy i modlitwy mędrca, ale określenia tego zazwyczaj nie używa się w sensie technicznym, ani w znaczeniu konkretnego elementu struktury utworu, a bardziej ze względu na dominującą tu tematykę. W odniesieniu do kryteriów gatunku enkomionu takie ograniczenie nie znajduje uzasadnienia.

Przykładając kategorie właściwości enkomionu do interesującego nas tekstu z Księgi Mądrości, trudno byłoby jednoznacznie obstawać przy wyznaczeniu początku enkomionu dopiero na Mdr 6,22, za czym opowiada się większość komentatorów. W proemiach enkomionów retorzy pozwalali sobie na ogromną swobodę, ale generalną ideą było krótkie zagajenie, w postaci bezpośredniego zwrotu do odbiorców $\mathrm{z}$ wezwaniem do wysłuchania oraz uprzedzeniem, że przedmiot pochwały jest taki, że żadne słowa do końca nie są w stanie tego wyrazić. Taka wstępna amplifikacja od razu podkreślała wagę podjętego tematu i tym bardziej zachęcała odbiorców do wysłuchania mowy, ale także antycypowała korektę wszelkiego typu niedoskonałości $\mathrm{w}$ procesie pochwały. O kształcie wstępu w dużej mierze decydowała sytuacja wygłaszania pochwały, jeśli więc enkomion służył celom doradczym lub osądzającym, domagał się często czegoś więcej niż tylko krótkiego zwrócenia uwagi na przedmiot pochwały ${ }^{32}$.

30 Por. np. A.G. Wright, The Structure of the Book of Wisdom, 175; P. Bizzeti, Il libro della Sapienza, 168-169; M.F. Kolarcik, The Ambiguity of Death, 22-24.

31 Por. np. A.G. Wright, The Structure of the Book of Wisdom, 173; D. Dimant, Pseudonymity in the Wisdom of Solomon, 246.

32 Por. np. Mikołaj z Myry, Progymnasmata 8, 50. 
Jeśli weźmiemy to pod uwagę, deklaracja podmiotu lirycznego w Mdr 6,22, dotycząca wyjawienia tajemnic mądrości i ukazania prawdy o niej, dobrze koresponduje z proemium epideiktycznego enkomionu. Jednakże pojawiający się tu spójnik ,zaś” (de) wskazuje, że mamy do czynienia z kontynuacją myśli i nawiązaniem do czegoś, co zostało powiedziane wcześniej, zatem początku proemium tego enkomionu możemy szukać wcześniej. Typową apostrofę do odbiorców powiązaną bezpośrednio z tematem mądrości znajdujemy w Mdr 6,9, gdzie autor zwraca się do mających władzę (tyrannoi), aby uczyli się mądrości. Apostrofa ta jednak opatrzona jest od razu ostrzeżeniami i poradami zapowiadającymi korzyści z przyjęcia takiej postawy: jeśli nauczą się mądrości - nie przepadną, znajdą obronę, zostaną uświęceni. Powtórzenie apostrofy do mających władzę (tyrannoi laōn) znajdujemy ponownie w 6,21, co można uznać za proemijną inkluzję i, podobnie jak w początkowym wezwaniu, mamy tu zachętę do okazywania czci mądrości oraz zapewnienie, że taka postawa zagwarantuje panowanie na wieki, co jest ewidentnym wskazywaniem na osiągnięcie wyjątkowej korzyści w przyszłości. Odwołanie się do przyniesienia pożytku, znajdujemy także w 6,25. Tak więc, po typowo epideiktycznej zapowiedzi, za jaką można uznać werset 6,22 dotyczący ukazywania czym i jaka jest mądrość, w 6,25 mamy pewnego rodzaju doprecyzowanie rzeczywistego celu wypowiedzi, którego uzasadnienie znajdujemy w wersecie poprzedzającym: "Wielu mędrców - wybawienie świata, a rozsądny król - spokój ludu" (Mdr 6,24). Powyższe aspekty wskazują, że celem skierowanego do odbiorców wezwania jest raczej poznawanie mądrości, uczenie się jej i kierowanie się jej zasadami (co zakłada wysiłek odbiorców przekraczający czas samej mowy), ponieważ to przynosi korzyść, niż tylko samo wygłoszenie podziwu dla cnoty mądrości. Cel więc enkomionu mądrości nie wygląda tu na czysto epideiktyczny, ale nie można pominąć tego, że także w typowo epideiktycznych enkomionach, zwłaszcza dotyczących rzeczy niematerialnych, jak np. idee, wartości czy umiejętności, dla właściwej realizacji pochwały w kwestiach szczegółowych autorzy progymnasmatów zalecali uczniom wskazywanie na to, jakie może to przynosić dobrodziejstwa i korzyści ludziom, bo z tego też powodu przedmiot pochwały był piękny i godny podziwu. 
Cechy proemium interesującego nas tu enkomionu mądrości właściwie nie przesądzają o klasyfikacji celu przypisanej doń perswazji. Wydaje się, że autor wykorzystuje tu w równej mierze siłę perswazyjną tkwiącą i w pochwale, i w zachęcie. Jeśli za jego początek przyjmiemy apostrofę z Mdr 6,9, to w znacznie większym stopniu proemium podkreśla doradczy cel pochwały, którą za chwilę mówca przedstawi odbiorcom. Jeśli natomiast za wstęp enkomionu przyjmiemy wersety 6,22-25, to mająca nastąpić pochwała może być rozpoznana jako mowa epideiktyczna. Zabiegi te jednak nie wykluczają się wzajemnie, a mogą skłonić odbiorcę do przyjęcia szerszej perspektywy i wyjścia poza cel delectare, tym bardziej, że enkomion nie otwiera Księgi Mądrości, jest poprzedzony długą argumentacją doradzającą jedne zachowania, a odradzającą inne, głównie przez ukazywanie skutków określonego sposobu myślenia, podejmowanych decyzji i wynikających z nich postaw ${ }^{33}$. Przejście więc w tym miejscu do pochwały mądrości jako cnoty pożądanej i godnej wszelkich zabiegów można rozpatrywać w kategoriach kolejnego kroku argumentacji doradczej, przy zachowaniu cech perswazji epideiktycznej i celów perswazji symbuleutycznej, co dla odbiorcy jest czytelne ${ }^{34}$.

Problem może się pojawić przy próbie wychwycenia przedmiotu pochwały. Zarówno bowiem proemium doradcze z Mdr 6,9-25, jak

33 Por. R.J. Clifford, Wisdom, 29.

34 Warto zaznaczyć, że późniejszym okresie enkomion wiązano z parenezą, dostrzegając jego możliwości dydaktyczne. Nie jest to oczywiście równoznaczne z tym, że każdy enkomion jest parenezą, ale często parenetyczne cechy wykazuje. Nie wydaje się jednak, aby to, co zostało zauważone przez późniejszych teoretyków nie miało odzwierciedlenia dużo wcześniej w praktyce. Kwestią sporną pozostaje zaszeregowanie parenezy do epideiktyki a nie symbuleutyki. Pseudo-Libanios w rozważaniach na temat stylu wprowadza wyraźne rozróżnienie pomiędzy nimi, sprowadzając to do kontekstu wypowiedzi. Według niego z doradzaniem mamy do czynienia wtedy, kiedy jest kwestia sporna i konieczność wyboru pomiędzy jedną rzeczą a drugą, a pareneza wiąże się z zachętą, w sytuacji, kiedy nie ma wątpliwości co do jej przedmiotu, ani alternatywy wyboru. Zob. Pseudo-Libanius, Epistolimaioi charakteres 5. Biorąc pod uwagę, że w Retoryce dla Aleksandra Anaksymenesa z Lampsakos, którą autor Księgi Mądrości mógł znać, czego nie można powiedzieć o pismach Libaniosa, zachęta jest ewidentnie przypisana doradzaniu i nie jest dla niej konieczna alternatywa, nie wydaje się zasadne takie rozgraniczenie. Zob. Anaksymenes, Rhetorica ad Alexandrum 1423ab, 1439b-1440a. 
i krótsze, bardziej epideiktyczne z 6,22-25, jednoznacznie wskazują na to, że przedmiotem mowy jest mądrość. Sugeruje to więc przede wszystkim rozpatrywanie jej aspektów, przejawów, skutków itp. W mowie zaś, która rozpoczyna się w Mdr 7,1 i rozciąga się aż do 9,18, uwaga w znacznej mierze skoncentrowana zostaje na osobie samego mówcy, który prezentuje siebie jako mędrca, jako tego, który został obdarowany rozsądkiem (fronēsis), duchem mądrości (pneuma sofias) i mądrość umiłował (efilēsa). Czy mamy więc do czynienia w Księdze Mądrości z enkomionem osoby mędrca, a nie rzeczy niematerialnej - wartości, jaką jest mądrość?

Jak już wyżej powiedziano, charakterystyczne w enkomionach toposy retorzy zalecali wybierać i prezentować w określony sposób. Pierwszym sugerowanym tematem po proemium było wychwalenie pochodzenia. Oczywiście zgodnie z topiką ogólną, że wychwalamy to, co zasługuje na pochwałę, a przemilczamy lub marginalizujemy to, co jest powszechne, przeciętne i nie warte wyróżniania. W typowym enkomionie na cześć mądrości należałoby się spodziewać przede wszystkim wskazywania na źródła mądrości, które same z siebie świadczą o nadzwyczajności owej cnoty. W przypadku enkomionu osoby powinniśmy znaleźć np. pochwałę nadzwyczajnych okoliczności narodzin, pochwałę rodu, ojczyzny, przodków.

We fragmencie Mdr 7,1-7, gdzie podmiot liryczny ujawnia swoją obecność i zaczyna wypowiadać się w pierwszej osobie, przybierając rolę mówcy-mędrca, mamy specyficzną, skondensowaną narrację o początkach życia aż do momentu obdarowania duchem mądrości. Budzi jednak zaskoczenie, że kiedy mówca mówi o swoim pochodzeniu, o czasie narodzin i wzrastaniu, pokazuje owe rzeczywistości jako całkiem powszednie, zwyczajne i wspólne wszystkim ludziom, co zupełnie nie pasuje do konwencji enkomionu. Paradoksalnie to właśnie podkreśla nadzwyczajność jego osoby i jego doświadczenia - owego mówcę cechuje bowiem świadomość znikomości ludzkiej natury, która skłania go do zwrócenia się w stronę Boga i do modlitwy. To właśnie ta postawa pokornej prośby do Boga jest dla mówcy pierwszym powodem do chluby, bo sprawiła, że został on 
wysłuchany i obdarowany rozsądkiem (fronēsis) i duchem mądrości (pneuma sofias) ${ }^{35}$.

To może nieco ryzykowna, ale niezwykle wyrafinowana i niewątpliwie doskonale się wpisująca w cele retoryki epideiktycznej strategia pochwały pochodzenia (genos). Mówca nie koncentruje się na wychwalaniu siebie, a nawet pozornie deprecjonuje swoją osobę, aby przez ten zaskakujący odbiorcę kontrast wydobyć to, co jest celem perswazji autora - pokazać odbiorcom prawdę o rzeczywistym pochodzeniu mądrości, o jakiej zamierza im mówić i ich do takiej właśnie mądrości przekonać, co im wcześniej zapowiadał. $\mathrm{W}$ tej części enkomionu definiuje ją więc przede wszystkim jako dar udzielany przez Boga, a nawet jako dar samego Boga, który się w ten sposób objawia, bo takie metonimiczne konotacje znaczeniowe niesie wyrażenie „duch mądrości” (pneuma sofias), którym się tu autor posługuje, analogicznie do tego, z czym mamy do czynienia w Iz 11,2, gdzie Duch Boży i Duch Mądrości są synonimami ${ }^{36}$. W ten sposób mówca realizuje cele enkomionu mądrości, wskazując jednoznacznie na absolutnie najlepsze źródło Mądrości, które jak i ona sama, godne jest czci i pragnienia. Do pochwały pochodzenia można by także włączyć tekst wersetu Mdr 8,3: „Sławi ją dobre pochodzenie, bo żyje wespół z Bogiem, a Władca wszystkiego ją kocha”, pojawia się on jednak na tyle daleko od proemium, że może także stanowić celowe powtórzenie, będąc albo podsumowaniem jakiejś sekcji, albo wprowadzeniem do nowej.

Dlaczego autor Księgi Mądrości posłużył się nietypową formą enkomionu, uciekając się do przemieszania form, które może utrudniać odbiorcom zatrzymanie się na rzeczywistym przedmiocie pochwały? Aby zrozumieć tę strategię trzeba zwrócić uwagę na jeszcze jeden istotny zabieg retoryczny, z jakim mamy tu do czynienia. Mówca-mędrzec nie przedstawia się w mowie wprost. Chociaż nagle w Mdr 7,1 zaczyna się wypowiadać w pierwszej osobie, wcale nie jest oczywiste, że to on jest podmiotem, choć nieujawnionym,

35 Na szczególne znaczenie modlitwy jako drogi do otrzymania daru mądrości zwraca uwagę M. Zieliński, „ «Przyszedł mi z pomocą duch mądrości» (Mdr 7,7)”, $38-40$.

36 Por. B. Poniży, Księga Mądrości, 244. 
pozostałych wypowiedzi w księdze. To jednak, co i jak o sobie mówi ów mówca-mędrzec podczas mowy pochwalnej, przynajmniej dla części odbiorców jest łatwe do rozpoznania i pociąga za sobą jego identyfikację z królem Salomonem. To celowy zabieg pseudonimii odczytywany przez zakładanych przez autora odbiorców. Stosowany był w retoryce w celu zbudowania autorytetu mówcy, który naśladował tego, który godny był naśladowania. Sięgnięcie po ideał mędrca w postaci króla Salomona jest typowym zabiegiem. Po pierwsze ideał ten jest mocno osadzony w tekście biblijnym, po drugie, takie naśladownictwo uznanego autorytetu było znane nie tylko w literaturze greckiej i wykorzystywane jako zabieg retoryczny, ale także było charakterystyczne dla sapiencjalnej literatury bliskowschodniej. Dobrze jest potwierdzone w licznych tekstach dydaktycznych, na przykład w egipskich instrukcjach, gdzie nauczyciel wypowiadający pouczenie do uczniów występuje w roli króla, który zasłynął w czasie swoich rządów z zapewnienia pomyślności dla państwa i narodu i swoje doświadczenie przekazuje potomnym, aby mogli powtórzyć jego sukcesy ${ }^{37}$.

Wbrew pozorom ów mówca-mędrzec nie jest anonimowy dla odbiorców w momencie, gdy zaczyna się wypowiadać. Autor Księgi Mądrości wykorzystuje liczne aluzje z innych ksiąg Biblii, gdzie mowa jest o Bożym darze mądrości powiązanym z Salomonem, aby zbudować autobiograficzną mowę pochwalną (periautologia) służącą unaocznieniu sposobów działania Mądrości Bożej na przykładzie życia Salomona (por. np.: 1 Krl 3,5-14; 5,17-21; 8,32; 2 Krl 1,8-12; $6,10)$. Aluzje pomagające odsłaniać różne przejawy Bożej Mądrości, które unaoczniało także życie króla Salomona, nie pojawiają się dopiero w enkomionie. Można je odnaleźć już w rozdziałach

37 Więcej na temat stosowania celowej pseudonimii w retoryce i technik mimesis zob. L.G. Perdue, Pseudonymity and Greco-Roman Rhetoric, 27-59. Autor zwraca uwagę, że pseudonimia wykorzystana została celowo przez twórców korpusu sapiencjalnego w Biblii i dotyczy ona nie tylko Księgi Mądrości. Analizuje różne sposoby realizacji mimesis w Księdze Mądrości, zarówno w odniesieniu do pseudonimii, zastosowanych gatunków wypowiedzi, jak i wartości przykładu naśladowania cnót Salomona. 
go poprzedzających ${ }^{38}$. W ten sposób autor przygotowuje odbiorcę. W momencie ujawnienia się mówcy i możliwości identyfikacji jego tożsamości, wcześniejsza argumentacja zaczyna ,pracować” i odbiorca może w prosty sposób wiązać to z przykładem z życia Salomona, a jednocześnie otrzymuje pogłębioną refleksję nad naturą Mądrości, do zdobywania której był dotąd zachęcany. Zastosowanie więc takiego dwutorowo przebiegającego enkomionu zwiększa możliwości perswazyjne i stanowi wsparcie dla argumentacji doradczej. Zwłaszcza wprowadzenie elementów pochwały osoby pełni funkcje typowe dla egzemplum w retoryce symbuleutycznej, gdzie przykład osoby, postaci wykorzystuje się jako wzorzec do naśladowania ${ }^{39}$. Dodatkowo strategia ,ujawnienia” Salomona jako mówcy-mędrca pozwala na wykorzystanie siły perswazyjnej, jaką można pozyskać z odwoływania się do etosu mówcy i to wykraczając poza granice samego enkomionu i rozciągając ów ethos na całość Księgi Mądrości. To usprawiedliwia wybór pochwały mędrca wygłaszanej w pierwszej osobie, co nie jest typowe dla epideiktycznych enkomionów, a charakteryzuje pochwały w retoryce sądowej, gdzie pełnią one funkcję mów apologetycznych.

W kontynuacji pochwały można zauważyć utrzymanie jej dwutorowej formy. To powoduje, że nie zawsze spotykamy przywołany powyżej i najczęściej zalecany schemat porządkujący poszczególne zagadnienia. Tocząca się narracja przeplata elementy pochwalne mówcy i mądrości. Nie umniejsza to czytelności wypowiedzi, a nawet nadaje mowie atrakcyjności, choć wymaga większego zaangażowania odbiorcy. Przyjrzyjmy się wybranym przez autora enkomionu topoi, stanowiącym trzon pochwały.

Kolejnym zalecanym elementem w dispositio enkomionu, po już przedstawionym proemium i pochwale pochodzenia, było wychwalenie wychowania (anatrophē). W pochwale mówcy-mędrca

38 Na temat celowego zabiegu przypisania mówcy-mędrcowi cech króla Salomona jako sposobu na budowanie autorytetu autora zob. np. D. Dimant, Pseudonymity in the Wisdom of Solomon, 245-252.

39 Na temat funkcji periautologii jako pozytywnego przykładu i jej możliwości wpływu na odbiorcę zob. np. Izokrates, Antidosis 6-8; Demostenes, De corona 3; Cyceron, Epistulae ad familiares 5.12.8; tenże, De inventione 1.16.22; Kwintylian, Institutio oratoria 11.1.15-18. 
spodziewać się można przedstawienia godnych szacunku i sławy nauczycieli, u których się uczył, nabytych umiejętności i wiedzy, w zdobywaniu których wzrastał i które potrafił z pożytkiem wykorzystywać, a w pochwale mądrości sposobów jej zdobywania i korzyści, jakie może przynieść.

Za odwołanie się do sławy nauczycieli można uznać przede wszystkim wersety Mdr 7,15-17a, ponieważ mówca-mędrzec mówi o Bogu, którego wcześniej nazwał dawcą ducha mądrości. Teraz rozwija tę myśl, pokazując Boga jako prawdziwego przewodnika mędrca, jako że od Boga pochodzą właściwe słowa, rozsądek, poznanie rzeczy i nabycie umiejętności. Edukacja mówcy jest więc godna najwyższej pochwały ze względu na samego Nauczyciela. Także sama mądrość, jako już przyjęty Boży dar, stała się mistrzynią (technitis) jego edukacji, bo pomagała poznawać wszystko to, co widoczne i co ukryte $(7,21)$. Dlatego też zdobyta przez niego wiedza o świecie, żywiołach, gwiazdach, roślinach, zwierzętach, popędach, ludziach i ich myśleniu staje się godna pochwały i jest najwyższej jakości (7,18-20).

Powodem do chluby dla mówcy jest także jego własna postawa wobec udzielonej mu Mądrości. Przede wszystkim dlatego, że potrafił docenić wartość tego daru. Uznał ją za cenniejszą od wszystkiego, co można zdobyć - wszystkich bogactw - zarówno materialnych, jak i duchowych (Mdr 7,8-9). Dzięki temu wraz z mądrością pozyskał wszystkie inne dary, choć się tego nie spodziewał. Ponadto powodem do pochwały jest to, że nie pragnie on zachować prawdy, którą pojął, tylko dla siebie. Mówca-mędrzec wyraźnie podkreśla, że dogłębne poznanie natury Mądrości zrodziło w nim pragnienie szczerego podzielenia się ze wszystkimi (odbiorcami mowy) pełnią tego bogactwa.

W odniesieniu do pochwały daru mądrości w anatrophē napotykamy pewnego rodzaju niejasność. Bez żadnych wątpliwości możemy włączyć w ten topos wychwalanie faktu, że mądrość przynosi wiedzę oraz wszystkie inne dary, które uznaje się za dobre (Mdr 7,11.21). Jest ona prezentowana jako ta, która uczy, obdarza, jest rodzicielką $(7,12)$. Płodność mądrości wyraża się nie tylko w tym, że przynosi obdarowanemu i rodzi w nim różne dobra, ale także i w tym, że czyni go chętnym do dzielenia się dobrem, jakie otrzymał. Największym pożytkiem, jaki może przynieść, jest przyjaźń Boga $(7,14)$. To mądrość udzielana przez Boga jest zarazem sprawczynią tak cennej 
relacji. Praktykowanie takiej mądrości zapewnia też trwanie relacji przyjaźni z Bogiem ${ }^{40}$.

Taki sposób wychwalania mądrości wyraźnie przesuwa akcent z pochwały cnoty i wartości na pochwałę osoby. Mądrość zostaje upersonifikowana, co jeszcze w początkowej fazie enkomionu nie było tak bardzo widoczne. Enkomion jest więc nadal realizowany w binarnej formie, ale ma komparatywny charakter pochwały dwóch osób. Pochwała mówcy-mędrca i jego dokonań służy ewidentnie temu, by w pełniejszy sposób uwypuklić pochwałę Mądrości ${ }^{41}$. Oczywiście w enkomionach stosowano takie środki, bo trudno jest wychwalać idee, wartości, cnoty bez uciekania się do przykładów i operując czysto teoretycznym językiem. W epideiktyce chwalenie pasywne, posługujące się np. ekfrazą, wyliczeniem itp., może być wystarczające, aby wzbudzić zachwyt i upodobanie w odbiorcach. Jeśli jednak mówca pragnie wywołać w odbiorcach także trwałe pożądanie przedmiotu pochwały lub jego naśladowanie, wtedy uosabianie wartości i idei, takich jak wolność czy sprawiedliwość, nadawanie im czynnych, osobowych cech podmiotu działającego daje większe możliwości perswazyjne. Są one dwojakie: można przywoływać egzempla osób, których życie i dzieła były potwierdzeniem owych idei lub wartości, albo personifikować owe idee. Autor enkomionu w Księdze Mądrości wybiera połączenie obydwu tych możliwości demonstrowania, co potwierdza jego doradcze cele perswazji. Najbardziej epideiktycznym fragmentem enkomionu jest poetycka ekfraza (Mdr 7,22-8,1), opisująca atrybuty Mądrości Bożej ${ }^{42}$. Celem ekfrazy jako rozbudowanej figury retorycznej było jasne i wyraziste opisanie czegoś, przedstawienie w taki sposób, aby zostało unaocznione odbiorcy. Dlatego odznaczała się wysokim stopniem szczegółowości

40 Na temat kategorii przyjaźni jako nowego sposobu wyrażania relacji z Bogiem zob. B. Poniży, „Sapiencjalne przejście”, 99-120. Na temat semantyki wyrażenia „przyjaciel Boga” w kontekście przymiotów Mądrości zob. np. M. Krawczyk, „Analiza leksykograficzna”, 13-17.

41 Na cechy pochwały „Pani Mądrości” zwraca uwagę J. Warzecha, „Personifikacja słowa i mądrości”, 31-34.

42 Na temat wykorzystania logicznych i patetycznych walorów argumentacji w tym fragmencie zob. B. Poniży, ,Wykład pochwalny”, 25-42 oraz tenże, Księga Mądrości, 258-272. 
opisu. Z czasem ewoluowała do samodzielnego gatunku wypowiedzi. Ekfraza włączana w mowy epideiktyczne, jak enkomiony, epitafia, panegiryki, hymny, zazwyczaj służyła do amplifikacji przedmiotu pochwały. Opisywano na przykład wydarzenia, postaci, zwierzęta, miasta, czas, przedmioty, rzeźby itp. Charakterystyczne dla stylu wypowiedzi ekfrazy było unikanie nadmiernego rozwlekania zdania, przyozdabiania go licznymi figurami ${ }^{43}$.

Warto zwrócić uwagę na to, że autor Księgi Mądrości wkłada opis Bożej Mądrości w usta mówcy-mędrca, który przedstawia ją jako coś, co dobrze poznał. Ekfraza ta w jakiś sposób odpowiada elementowi praxeis w porządku strukturalnym enkomionu. Przedstawiane atrybuty Mądrości są bowiem porządkowane według pewnego klucza, co do właściwości jej ducha, „wyglądu” i sposobów działania, objawiania się. Cała uwaga skoncentrowana jest na przedmiocie pochwały i ponownie unaocznia odbiorcy, co jest jej istotą, a także pomaga uzmysłowić mu, że Mądrość, o której mowa, jest z jednej strony czymś nieuchwytnym, przynależnym Bogu, a z drugiej strony immanentnym, dającym się poznać i doświadczyć. Cechy Bożej Mądrości eksponowane są także w sylogistycznych solilokwiach (Mdr 8,5-8), w których mówca-mędrzec prowadzi odbiorcę do oczywistego wniosku, że Mądrość Boża jest tym, czego najbardziej powinien on poszukiwać i pragnąć ponad wszelkiego typu bogactwa, wiedzę, dary, cnoty. Wersety te można także włączyć do ekfrazy, ponieważ nie wyklucza ona takiego sposobu przedstawiania, ale przerwana jest wtrąceniem w Mdr 8,2, gdzie mówca powraca do spojrzenia na Mądrość z perspektywy swojego życia, a kontynuuje tę pochwalną refleksję od 8,9. Ma ona również charakter pochwały w zakresie praxeis, tym razem w odniesieniu mówcy-mędrca do siebie samego.

Do działań, które zasługują na pochwałę i które wyróżniają mówcę od innych, zaliczane są: poszukiwanie, zachwyt, umiłowanie, zaślubienie i współzamieszkiwanie z Mądrością (Mdr 8,2.9) oraz podejmowanie decyzji, które przynoszą mu chlubę ${ }^{44}$. Użyty tu język

43 Na temat ekfrazy jako retorycznej formy wypowiedzi zob. np. R. Słodczyk, „Hypotypoza”, 143-159.

44 Szczegółowo metaforę małżeństwa z mądrością analizuje M. Zieliński, „La morte”, 313-317. 
odwołuje się do uosobionej Mądrości, która jest traktowana jak kobieta $^{45}$. Mówca, mając wydoskonaloną cnotę rozsądku, był w stanie rozważyć korzyści płynące z zażyłości z Mądrością Bożą, takie jak sława z wiedzy i posługiwania się słowem, bogactwa, zaspokojenie przyjaźni, a także nieśmiertelność (8,16-18). Dla odbiorców jawi się przede wszystkim jako przykład godny do naśladowania. Zachwyt wzbudza niezwykle bliska więź z Mądrością, która zapewnia zażyłą przyjaźń z Bogiem ${ }^{46}$. Wartość tej pochwalnej przemowy polega na tym, że choć efekty są wyjątkowe, to nie są ekskluzywne i możliwe do osiągnięcia dla każdego, kto - z równym jak mówca-mędrzec zaangażowaniem - poświęci swoje życie na budowanie relacji z Mądrością, której udziela sam Bóg, i ku temu skieruje swoje pragnienia. Urealnia te możliwości katalog chwalebnych dokonań mówcy-mędrca, zarówno tych, które są jeszcze podawane jako potencjalne, mające nastąpić w przyszłości (8,10-15: chwała u ludu, cześć u starszych, podziw możnych, uznanie dla dzieł i sprawiedliwości w wydawaniu wyroków, wieczna pamięć wśród potomnych, panowanie nad innymi ludami, męstwo na wojnie, lęk wśród tyranów), jak i tych, które już są faktem, a wymienia się je w modlitewnym epilogu (9,7-8: król i sędzia swojego ludu, budowniczy świątyni dla Boga dawcy Mądrości). Zestawione razem niewątpliwie nobilitują mówcę w oczach odbiorców, ale też amplifikują działanie Bożej Mądrości, dzięki której wszystko to osiągnął.

Enkomion kończy modlitwa mówcy o Mądrość. O trudnościach z ustaleniem granicy zakończenia (Mdr 9,18 czy 11,1) była już mowa wcześniej. To, że pojawiająca się w tekście modlitwa włożona w usta mówcy-mędrca pełni funkcję epilogu enkomionu, sugerują powtórzenia treści zawartych już wcześniej w proemium oraz w pochwałach pochodzenia. Charakterystyczne podsumowanie (recapitulatio) z Mdr 8,18-21 sygnalizuje fazę końcową. Mówca przypomina, że rozważał wszystko to, co dotyczy mądrości, zastanawiał się, jak można ją zdobyć, że miał wszelkie fizyczne i duchowe warunki do tego, by osiągnąć sukces, ale w żaden sposób nie mogło mu to

45 Por. M. Zieliński, „«Przyszedł mi z pomocą duch mądrości» (Mdr 7,7)”, 44.

46 Por. E.G. Clarke, The Wisdom of Solomon, 57. 
zapewnić posiadania mądrości, której pragnął, ponieważ udziela jej tylko Bóg, dlatego do Niego skierował swoje prośby.

Jeśli zakończeniem enkomionu była modlitwa, zazwyczaj używano środków retorycznych z zakresu pathos: wzniosłego, afektywnego języka, bezpośrednich inwokacji. Sumaryczne powtórzenia treści z wcześniejszych pochwał wybrzmiewały ponownie w bardziej uroczystym języku. W przypadku naszego enkomionu, w pochwale Mądrości, która jest Bożym darem, modlitwa jest szczególnie uzasadniona ${ }^{47}$. Była ona dla mówcy warunkiem otrzymania tego daru. Nie oznacza to jednak wcale, że przytoczenie słów modlitwy pełni tylko funkcję amplifikacji pochwały. Jeśli enkomion jest właściwie zbudowany, zakończenie powinno dobrze korespondować z założeniami podawanymi we wstępie. Gdy weźmiemy to pod uwagę, nasuwają się dwa podstawowe wnioski.

Pierwszy dotyczy tego, że celem autora było nie tyle zatrzymanie się nad walorami mądrości, aby wychwalać jej przymioty i wzbudzać chwilowy zachwyt w odbiorcach (pathos), ile przekazać im, czym jest mądrość, ,zdefiniować” ją we właściwy sposób, dlatego elementy laudatywne wypowiedzi podporządkowane są celom dydaktycznym. Mówca zapowiadał we wstępie, że chce udzielonym mu darem dzielić się z innymi i nie chce go zatrzymać tylko dla siebie. Rozpoznana właściwie mądrość ma przynieść korzyść odbiorcom. Tak samo jak wcześniej mówca modlił się o mądrość i otrzymał ją od Boga, tak teraz słowa końcowej modlitwy obejmują również odbiorców, którzy w niej w ten sposób współuczestniczą i mają szansę na włączenie w działanie Boga obdarowującego mądrością. Można więc uznać, że modlitwa ta $\mathrm{w}$ niniejszym enkomionie realizuje cele perswazji doradczej, która zmierza ku skłonieniu odbiorców do podjęcia określonych wyborów, decyzji, działań i utrwalenia pożądanych postaw. Sama w sobie jest tym właściwym działaniem prowadzącym do osiągnięcia celu. Potwierdza to tym samym, że enkomion został tu użyty jako rodzaj argumentu doradczego, perswadującego pragnienie i działanie zmierzające do otrzymania daru Mądrości Bożej.

47 Na temat afektywnych walorów modlitwy i funkcji emocji w tym fragmencie zob. M. Witte, „Emotions in the Prayers of the Wisdom of Solomon”, 164-173. 
Drugi wniosek wiąże się z wątpliwościami, odnośnie zakończenia enkomionu. W Mdr 6,22, w zapowiedzi mówcy, mamy wyraźne wskazanie, że zamierza on wydobywać prawdę o mądrości, śledząc jej przejawy od początku stworzenia. W dotychczasowej treści enkomionu mówca-mędrzec czyni wzmiankę tylko o zstępowaniu mądrości przez pokolenia na dusze święte $(7,27)$ oraz o tym, że jest ona wtajemniczona w wiedzę Boga $(8,4)$. Dopiero w modlitwie mamy stwierdzenie, że Mądrość Boża uczestniczyła w stwarzaniu świata i zna wszystkie dzieła Boga $(9,9)$. Pojawienie się dopiero w tym miejscu istotnej informacji zapowiedzianej w proemium enkomionu może rodzić słuszne wątpliwości, czy rzeczywiście modlitwa stanowi zakończenie tego enkomionu, tym bardziej, że najbardziej adekwatną realizacją owej proemijnej zapowiedzi jest dopiero mowa z Mdr 10,1-21, a w modlitwie ta kwestia zostaje tylko wprowadzona. Zasadne jest więc to, że można uznać mowę z Mdr 10,1-21 za kontynuację modlitwy mędrca ${ }^{48}$. Uznawanie, że w 10,1-21 mamy do czynienia z kontynuacją enkomionu jest o tyle zasadne, że wykazywanie dokonań Mądrości Bożej w historii odpowiada kategoriom przewidywanym dla praxeis i może być traktowane jako narracja o charakterze pochwalnym. Można to także uznać za synkrisis, czyli ocenę porównawczą, wykorzystującą zestawienie z rzeczą przeciwną, aby wydobyć istotę tego, co jest oceniane ${ }^{49}$. Dlatego w tej narracji pojawiają się elementy przeciwne Bożej Mądrości, widoczne w nawiązaniach do postaci Kaina, potopu, wieży Babel, Sodomy i okolicznych miast itd., poprzez które autor wydobywa moc działającej Bożej Mądrości ocalającej sprawiedliwych ${ }^{50}$. Według zaleceń późniejszych autorów progymnasmatów synkrisis było pożądane przed epilogiem enkomionu z powodów dużej siły perswazyjnej, jaka tkwi w zestawieniach przeciwstawnych ${ }^{51}$. Trudno ocenić, czy taka praktyka była powszechna wcześniej, kiedy komponowano Księgę

48 Por. A.T. Glicksman, Wisdom of Solomon 10, 89.

49 Tak jak i Teon z Aleksandrii, Progymnasmata 113-114, większość autorów późniejszych progymnasmatów odnosiła się do porównania, omawiając je najczęściej po pochwale i naganie. Por. np. Aftoniusz Sofista, Progymnasmata 42-43; Hermogenes, Progymnasmata 18; Mikołaj z Myry, Progymnasmata 59-60.

50 Por. S. Burkes, ,Wisdom and Apocalypticism”, 37.

51 Zob. Aftoniusz Sofista, Progymnasmata 36. 
Mądrości, ale synkrisis jako formę wypowiedzi możemy znaleźć często w piśmiennictwie żydowskim przełomu er, niekoniecznie powiązaną z pochwałą ${ }^{52}$. Być może ze względu na kompozycję całości utworu ten potencjalny element enkomionu został przesunięty poza epilog, tworząc pomost z dalszą częścią dowodzenia, która nie ma już charakteru pochwalnego. W modlitwie dodano łącznik $(9,18)$ wprowadzający do porównawczej narracji. Trudno w ramach krytyki historycznej rozstrzygnąć tę kwestię, jednak mowa z 10,1-21 zupełnie nie ma cech zakończenia czy podsumowania i płynnie łączy się z treściami dalszej części utworu, które jednak nie mają już cech typowych dla enkomionu. Skoro więc sekcja ta z jednej strony ma związek z enkomionem, z drugiej zaś z dalszą częścią (rozdziały Mdr 11-19), to można uznać ją za formę łącznika, przejścia strukturalnego ${ }^{53}$. Wówczas modlitwę mówcy-mędrca należy uznać za zakończenie enkomionu, jako formy wypowiedzi w ramach większej całości.

\section{Podsumowanie}

Autor Księgi Mądrości wykazuje się kunsztem literackim i retorycznym. Posługuje się różnymi środkami retorycznymi z dużą swobodą, wykorzystując je w swojej perswazji skoncentrowanej wokół tematu mądrości.

Jednym z wykorzystanych przez niego gatunków wypowiedzi jest enkomion, który podporządkowany został perswazji doradczej dominującej w Księdze Mądrości. Autor wykorzystuje walory enkomionu jako mowy pochwalnej, jednak nie ogranicza się do ukazania odbiorcom piękna i walorów mądrości. Przede wszystkim skupia swoją uwagę na tym, aby zachęcić odbiorców do poszukiwania, przyjęcia oraz praktykowania z pożytkiem daru mądrości i pod tym kątem dobiera odpowiednią strategię dotarcia do odbiorcy. W tym celu koncentruje się przede wszystkim na tym, aby właściwie zdefiniować,

52 Por. np. A. Kubiś, „Rhetorical Syncrisis”, 488-490.

53 Różne hipotezy co do funkcji 10. rozdziału w strukturze Księgi Mądrości oraz jego cech literackich i perswazyjnych przedstawia w swojej monografii A.T. Glicksman, Wisdom of Solomon 10, 88-100. 
o jaką mądrość mu chodzi, aby to właśnie taka mądrość stała się przedmiotem dążenia adresatów jego mowy. Wybór enkomionu może więc nieco zaskakiwać z uwagi na to, że argumentacja logiczna nie dominuje w tej formie wypowiedzi, a to wydaje się być najbardziej pożądane dla osiągnięcia zamierzonego celu. Strategia autora nie jest jednak chybiona.

Po pierwsze autor poprzedza enkomion długą argumentacją o charakterze doradczym, która choć nie jest skupiona na mądrości, przynajmniej w sposób oczywisty, jest przygotowaniem odbiorcy na dalsze argumenty. W enkomionie autor potwierdza swoje zachęcające cele perswazyjne, co zresztą ujawnia odbiorcom. Dispositio enkomionu nie odzwierciedla sztywnej struktury ćwiczeń retorycznych. Autor realizuje mowę pochwalną z dużym rozmachem. Po pierwsze wykorzystuje techniki mimesis, aby przez odwołanie się do autorytetu uznanego za mędrca króla Salomona pochwałę mądrości włożyć w jego usta. Po drugie konstruuje złożony enkomion, w którym przeplatają się pochwały mądrości jako pożądanego daru, którego jedynym dawcą i źródłem jest sam Bóg, i pochwały uosobionej Mądrości, która jest sprawczynią wszelkich dobrych darów oraz zapewnia przyjaźń z Bogiem z opartą na paradoksie periautologią mówcy-mędrca, w którym można rozpoznać króla Salomona. Pomimo tego, że enkomion włożony jest w usta mówcy-mędrca i część tekstu poświęcona jest pochwale jego życia, to nie on i jego dokonania są przedmiotem pochwały. Postać owa służy realizacji celów retoryki doradczej, stanowiąc typ argumentacji przez przykład życia, a także zwiększa możliwości epideiktyczne enkomionu w celu ukazywania sposobów działania i dzieł Mądrości Bożej. Mówca tak prezentuje swoje życie, że dla odbiorców staje się jasne, że gdyby nie dar Mądrości Bożej, nie byłoby ono godne pochwały - wszystko bowiem, co przyniosło mu chlubę, z uprzedniego obdarowania wynika.

Autor posługuje się charakterystycznymi elementami dispositio enkomionu zgodnie z zalecaną dla niego topiką, taką jak pochwała pochodzenia, pochwała wychowania, pochwała cnót, czynów, sprzyjającego losu, i operuje poszczególnymi właściwościami zgodnie ze swoimi założeniami perswazyjnymi. Swoisty synkretyzm enkomionu, zawarcia pochwał mądrości prezentowanych w różnych odsłonach, dał autorowi możliwość wykorzystania argumentacji logos, 
ethos i pathos, co sprzyja przekonaniu odbiorcy do poszukiwania i życia z wartą wszelkich pragnień i dążeń Mądrością udzielaną przez samego Boga tym, którzy o to Go proszą.

\title{
The Wisdom Encomium and Its Persuasive Function in the Book of Wisdom
}

\begin{abstract}
The Book of Wisdom is considered a coherent text characterized by genre syncretism. The purpose of this article is to examine the praise of wisdom in the Book of Wisdom for its persuasive functions in the book.

The encomium was used in the analysis as a typical genre of epideictic rhetoric. The text of the praise was analyzed from the perspective of the features distinguishing this genre and determining its underlying structure.

The analysis led to the conclusion that the author used the possibilities of the genre to teach the recipients what wisdom they should seek and to encourage them to take actions to achieve it. The encomium in the Book of Wisdom was subordinated to advisory rhetoric and is an essential element in the work's structure.
\end{abstract}

Keywords: Wisdom of Solomon, encomium, praise of wisdom, epideictic rhetoric, deliberative rhetoric

\section{Bibliografia}

Arystoteles, Retoryka. Retoryka dla Aleksandra. Poetyka. Wstęp, przekład i komentarz H. Podbielski, Warszawa 2009.

Bizzeti, P., Il libro della Sapienza. Struttura e genere letterario (RivBSuppl. 11), Brescia 1984.

Burgess, T.Ch., Epideictic Literature (Studies in Classical Philology 3), Chicago 1902.

Burkes, S., „Wisdom and Apocalypticism in the Wisdom of Solomon”, Harvard Theological Review 95 (2002) nr 1, 21-44.

Cicero Marcus Tullius, De Inventione. Retorici libriduoqui vocantur de inventione, E. Stroebel (red.), Lipsiae 1915.

Cicero Marcus Tullius, De oratore. Brutus, Orator, H.M. Hubbel (red.), Cambridge-London 1939.

Cicero Marcus Tullius, Epistulae ad familiares, W.G. Williams (red.), Harvard 1927.

Clarke, E.G., The Wisdom of Solomon, Cambridge 1973.

Demosthenis, Orationes, recognovit S.H. Butcher, I-III, Oxonii 1903.

Dimant, D., „Pseudonymity in the Wisdom of Solomon”, w: N.F. Marcos (red.), La Septuaginta en la investigacion contemporánea, Madrid 1985, 243-255. 
Dionis Prusaensis, quem vocant Chrysostomum, quae exstant omnia, edidit, apparatu critico instruxit..., Hans von Arnima, t. 1-2, wyd. 2, Berolini 1962 (wyd. 1, 1893-1896).

Dodson, J.R., The 'Powers' of Personification. Rhetorical Purpose in the Book of Wisdom and the Letter to the Romans, Berlin-New York 2008.

Dupont-Sommer, A., ,De l'immoralité astrale dans la Sagese de Salomon”, Revue des Études Grecques 62 (1949) fasc. 289-290, 80-87.

Gilbert, M., The Literary Structure of the Book of Wisdom. A Study of Various Views, w: A. Passaro, G. Bellia (red.), The Book of Wisdom in Modern Research. Studies on Tradition, Redaction, and Theology, Berlin-New York 2005, 19-32.

Glicksman, A.T., Wisdom of Solomon 10. A Jewish Hellenistic Reinterpretation of Early Israelite History through Sapiential Lenses (DCLS 9), Berlin-Boston 2011.

Isocrates. Isocrates with an English Translation in three volumes by George Norlin, Cambridge - London 1980.

Jordan, M., ,Ancient Philosophic Protreptic and the Problem of Persuasive Genre", Rhetorica 4 (1986) nr 4, 309-333.

Kolarcik, M.F., ,The Ambiguity of Death in the Book of Wisdom 1-6: A Study of Literary Structure and Interpretation" (AnBib 127), Rome 1991.

Krawczyk, M., „Paradoks czystości. Interpretacja oraz implikacje teologiczne słowa „katharos” (czysty) oraz „,katharotes” (czystość) w Mdr 7,22-28”, Collectanea Theologica 86 (2016) nr 1, 5-24.

Kubiś, A., „Rhetorical Syncrisis in the Johannine Presentation of Jesus and Peter", Biblical Annals 7 (2017) nr 4, 487-529.

Maries, L., „,Remarques sur la forme poétique du Livre de la Sagesse (1,1-9,17)”, Revue Biblique 5 (1908) nr 2, 251-257.

McGlynn, M., Divine Judgment and Divine Benevolence in the Book of Wisdom (WUNT 139), Tübingen 2001.

Nickelsburg, G.W.E., Jewish Literature Between the Bible and the Mishnah: A Historical and Literary Introduction, Philadelphia 1981.

Pepe, C., „(Re)discovering a Rhetorical Genre: Epideictic in Greek and Roman Antiquity", Res Rhetorica 4 (2017) nr 1, 17-31.

Pepe, C., The Genres of Rhetorical Speeches in Greek and Roman Antiquity, Leiden-Boston 2013.

Offerhaus, U., Komposition und Intention der Sapientia Salomonis, Bonn 1981. Perdue, L.G., „Pseudonymity and Greco-Roman Rhetoric. Mimesis and the Wisdom of Solomon", w: J. Frey, J. Herzer, M. Janssen, C.K. Rothschild (red.), Pseudepigraphie und Verfasserfiktion in frühchristlichen Briefen, Tübingen 2009, 27-59. 
Perdue, L.G., „Rhetoric and the Art of Persuasion in the Wisdom of Salomon”, w: S.E. Porter, A.W. Pitts (red.), Christian Origins and Hellenistic Judaism (TENT 10), Leiden-Boston 2013, 341-371.

Pernot, L., Epideictic Rhetoric. Questioning the Stakes of Ancient Praise, Austin 2015.

Poniży, B., „Sapiencjalne przejście od „przymierza” do „przyjaźni” z Bogiem”, Verbum Vitae 4 (2003), 99-120.

Poniży, B., Księga Mądrości (NKB.ST 20), Częstochowa 2012.

Poniży, B., „Wykład pochwalny charakterystyki Mądrości (Mdr 7,22b-8,1)”, Tarnowskie Studia Teologiczne 23 (2004), 25-42.

Progymnasmata. Greckie ćwiczenia retoryczne i ich modelowe opracowanie (Źródła i monografie 402), Przekł. i oprac. H. Podbielski, Lublin 2013.

Reese, J.M., „A Semeiotic Critique: With Emphasis on the Place of the Wisdom of Solomon in the Literature of Persuasion", Semeia 50 (1990), 229-242.

Reese, J.M., Hellenistic Influence on the Book of Wisdom and Its Consequences (AnBib 41), Rome 1970.

Reese, J.M., „Plan and Structure in the Book of Wisdom”, Catholic Biblical Quarterly 27 (1965) nr 4, 391-399.

Reymond, E.D., „The Poetry of the Wisdom of Solomon Reconsidered”, Vetus Testamentum 52 (2002) fasc. 3, 385-399.

Shekan, P.W., „The Text and Structure of the Book of Wisdom”, Traditio 3 (1945), 1-12.

Słodczyk, R., „Hypotypoza - zapoznana figura na mapie relacji werbalno-wizualnych", Ruch Literacki 59 (2018) nr 2, 143-159.

Tanzer, S.J., „The Wisdom of Solomon”, w: C.A. Newsom, S.H. Ringe (red.), Women's Bible Commentary. Expanded Edition with Apocrypha, Louisville 1992, 1998.

Thackeray, H.S.J., „Rhythm in the Book of Wisdom”, The Journal of Theological Studies 6 (1905) nr 22, 232-237.

Quitilian, Institutio oratoria, t. 1-4, H.E. Butler (red.), London-New York 1920-1922.

Warzecha, J., „Personifikacja słowa i mądrości jako przygotowanie Wcielenia”, Collectanea Theologica 70 (2000) $\mathrm{nr}$ 4, 21-35.

Vílchez, J., „Księga Mądrości”, w: W.R. Farmer (red.), W. Chrostowski (red. wyd. pol.), Międzynarodowy komentarz do Pisma Świętego. Komentarz katolicki i ekumeniczny na XXI wiek, Warszawa 2000, 795-809.

Winston, D., Wisdom of Solomon (AB 43), Garden City 1979.

Witte, M., „Emotions in the Prayers of the Wisdom of Solomon”, w: S.C. Reif, R. Egger-Wenzel (red.), Ancient Jewish Prayers and Emotions, Berlin-Boston 2015, 161-176.

Wright, A.G., „Numerical Patterns in the Book of Wisdom”, The Catholic Biblical Quarterly 29 (1967) nr 3, 524-538. 
Wright, A.G., „The Structure of the Book of Wisdom”, Biblica 48 (1967) nr 2, $165-184$.

Zieliński, M., „La morte nel libro della Sapienza. Il raporto tra la figura della Sapienza e la realta della morte", Biblical Annals 7 (2017) nr 3, 307-322.

Zieliński, M., „«Przyszedł mi z pomocą duch mądrości» (Mdr 7,7). Relacja między starotestamentową mądrością a działaniem Ducha Świętego", Verbum Vitae 37 (2020) nr 1, 35-47. 